\title{
Tingkat Pengetahuan Pasien Hipertensi tentang Penggunaan Obat di Puskesmas Kota Malang
}

\author{
Hananditia R. Pramestutie, Nina Silviana \\ Program Studi Farmasi, Fakultas Kedokteran, Universitas Brawijaya, Malang, Indonesia
}

\begin{abstract}
Abstrak
Hipertensi merupakan keadaan meningkatnya tekanan darah sistolik $\geq 140 \mathrm{mmHg}$ dan atau tekanan darah diastolik $\geq 90 \mathrm{mmHg}$. Pengetahuan yang harus dimiliki oleh pasien hipertensi meliputi arti penyakit hipertensi, penyebab hipertensi, gejala yang sering menyertai dan pentingnya melakukan pengobatan yang teratur dan terus-menerus dalam jangka panjang serta mengetahui bahaya yang ditimbulkan jika tidak minum obat. Pengetahuan ini penting untuk menunjang keberhasilan terapi hipertensi. Penelitian ini bertujuan untuk mengetahui tingkat pengetahuan pasien hipertensi tentang pengobatannya di Puskesmas Kota Malang. Penelitian ini menggunakan metode penelitian observasional prospektif. Pemilihan sampel pasien dan pemilihan Puskesmas menggunakan metode teknik pengambilan sampel secara nonrandom sampling (purposive sampling) dan harus memenuhi kriteria inklusi yang sudah dibuat oleh peneliti. Hasil penelitian ini adalah pasien hipertensi yang memiliki tingkat pengetahuan cukup sebesar 69 responden (72,63\%). Pasien yang mempunyai tingkat pengetahuan baik sebesar 26 responden (27,37\%). Tidak ada responden yang memiliki tingkat pengetahuan buruk. Simpulan dari penelitian ini adalah sebagian besar pasien hipertensi di Kota Malang memiliki tingkat pengetahuan cukup tentang pengobatannya.
\end{abstract}

Kata kunci: Hipertensi, tingkat pengetahuan pasien

\section{The Knowledge Level of Hypertension Patients for Drug Therapy in the Primary Health Care of Malang}

\begin{abstract}
Hypertension is a persistent blood pressure in which systolic pressure $\geq 140 \mathrm{mmHg}$ and diastolic pressure $\geq 90 \mathrm{mmHg}$. The knowledge that should be owned by patients with hypertension is the meaning, causes, symptoms and treatment of hypertension. This knowledge is important to support the success of hypertension therapy. The aim of this research was to determine the knowledge level of hypertension patients about their drug therapy in the primary health care of Malang. This research used observational study methods. The selection of the patients and the primary health care was done using non-random sampling technique (purposive sampling). The subject who meet the inclusion criteria were involved. The result of this study revealed that the patients with hypertension who have a sufficient level of knowledge were 69 respondents $(72,63 \%)$. Patients who have a good criteria were 26 respondents $(27,3763 \%)$. There is no patient with low level of knowledge in this research. The conclusion from this study is most patients with hypertension in Primary Health Care Malang have enough knowledge about their treatment.
\end{abstract}

Key words: Hypertension, patient knowledge 


\section{Pendahuluan}

Hipertensi merupakan tekanan darah persisten dimana tekanan sistoliknya $\geq 140 \mathrm{mmHg}$ dan tekanan diastolik $\geq 90 \mathrm{mmHg}$. Hipertensi dikenal secara luas sebagai salah satu penyakit kardiovaskular. Penyakit ini, diperkirakan telah menyebabkan $4,5 \%$ dari beban penyakit secara global dan memiliki prevalensi hampir sama besar di negara berkembang maupun di negara maju. Hipertensi merupakan salah satu faktor risiko utama gangguan jantung. Selain dapat mengakibatkan gagal jantung, hipertensi dapat berakibat terjadinya gagal ginjal maupun penyakit serebrovaskular. Penyakit ini bertanggung jawab terhadap tingginya biaya pengobatan dikarenakan alasan tingginya angka kunjungan ke dokter, perawatan di rumah sakit dan penggunaan obat jangka panjang. ${ }^{2,3}$

Terapi untuk pasien hipertensi terdiri dari terapi farmakologis dan terapi non farmakologis. Terapi farmakologis dapat menggunakan obat-obatan untuk menurunkan tekanan darah. Terapi non farmakologis dapat dilakukan dengan memodifikasi gaya hidup seperti menurunkan berat badan, berhenti merokok, menghindari alkohol, mengurangi stres, memperbanyak olah raga dan istirahat yang cukup. ${ }^{2,3}$

Hipertensi merupakan gangguan kesehatan yang sering dijumpai dan termasuk kesehatan masyarakat yang perlu segera ditanggulangi. Tanpa penanggulangan yang baik, penyakit ini akan mengganggu kehidupan penderita sehari-hari dan cenderung dapat menimbulkan komplikasi. Hambatan dalam pengobatan ini disebabkan penderita yang lalai, tidak mendengarkan nasehat dokter atau apoteker, kurang pengetahuan dan pemahaman dalam minum obat serta kurangnya pengetahuan mengenai obat yang benar sehingga perlu kerjasama yang erat antara tenaga kesehatan dan pasien. Pengertian yang salah tentang perawatan hipertensi sering terjadi karena kurangnya pengetahuan. ${ }^{4,5}$

Pengetahuan merupakan tingkat perilaku penderita dalam melaksanakan pengobatan dan perilaku yang disarankan oleh dokter atau orang lain. Pengetahuan merupakan domain yang sangat penting untuk terbentuknya perilaku seseorang. Pengetahuan yang harus dimiliki oleh pasien hipertensi meliputi arti penyakit hipertensi, penyebab hipertensi, gejala yang sering menyertai dan pentingnya melakukan pengobatan yang teratur dan terus-menerus dalam jangka panjang serta mengetahui bahaya yang ditimbulkan jika tidak minum obat. ${ }^{6}$ Tujuan penelitian ini adalah ingin mengetahui tingkat pengetahuan pasien hipertensi tentang pengobatannya di Puskesmas Kota Malang. Penelitian ini dilakukan di Puskesmas Kota Malang karena peneliti melihat bahwa penelitian serupa belum pernah dilakukan di Puskesmas Kota Malang. Di Kota Malang terdapat 15 Puskesmas yang tersebar di berbagai kecamatan. Dan dari 15 puskesmas tersebut belum terdapat data mengenai tingkat pengetahuan pasien tentang pengobatannya.

\section{Metode}

Penelitian ini merupakan penelitian observasional prospektif dengan analisis deskriptif pada seluruh pasien hipertensi yang datang ke Puskesmas Kota Malang untuk menebus resep atau salinan resep selama periode Maret-April 2014. Sampel diambil dengan teknik non random sampling yaitu secara purposive sampling. Sampel dalam penelitian ini adalah pasien hipertensi dan puskesmas tempat dilakukan penelitian. Sampling dalam penelitian ini dilakukan selama dua bulan. Berdasarkan hasil purposive sampling diketahui terdapat tiga puskesmas tempat dilakukan penelitian yaitu Puskesmas Dinoyo, Puskesmas Kendalsari, dan Puskesmas Kedung Kandang.

Besar sampel pada penelitian ini dihitung 
dengan menggunakan metode judgement.

Peneliti melakukan wawancara pada tiga puskesmas tempat dilakukan penelitian. Rata -rata pasien hipertensi yang menebus obat dengan membawa resep atau salinan resep pada ketiga puskesmas adalah minimal dua pasien/hari. Berdasarkan perhitungan besar sampel diperoleh sampel sebesar 78 responden dalam waktu dua bulan untuk tiga puskesmas.

Kriteria inklusi pasien dalam penelitian ini adalah pasien hipertensi yang menebus resep atau salinan resep di Puskesmas Kota Malang, pasien dengan lama menderita hipertensi minimal selama dua bulan, pasien hipertensi yang bersedia mengisi kuisioner dan pasien hipertensi yang bersedia mengikuti penelitian. Kriteria inklusi puskesmas dalam penelitian ini adalah puskesmas yang memiliki pasien hipertensi yang menebus obat di apotek. Kriteria eksklusi pasien dalam penelitian ini adalah keluarga pasien yang datang menebus resep di Puskesmas Kota Malang dan tidak dapat berkomunikasi dengan baik. Kriteria eksklusi puskesmas dalam penelitian ini yaitu puskesmas yang tidak menerima mahasiswa magang atau mahasiswa yang melakukan penelitian di puskesmas tersebut.

Seluruh pasien yang telah memenuhi kriteria inklusi kemudian diberikan penjelasan untuk kesediaan pasien terlibat dalam penelitian, lalu pasien diminta untuk mengisi dan menandatangani informed consent. Pasien mengisi kuisioner dengan panduan oleh peneliti untuk pengambilan data kuisioner.

Penelitian ini menggunakan instrumen kuesioner tingkat pengetahuan pasien dalam meminum obat yang terdiri dari 12 pertanyaan yaitu pengetahuan pasien dalam hal fungsi obat, nama obat yang diminum setiap harinya, dosis obat, waktu yang tepat untuk minum obat, cara penggunaan obat, cara kerja obat di dalam tubuh, jumlah obat yang diminum, penggunaan obat setiap hari, akibat apabila obat tidak diminum setiap hari, interaksi obat, tindakan yang dilakukan bila lupa minum obat dan cara penyimpanan obat. Pada kuisioner juga terdapat data tambahan berupa identitas dan lama menderita hipertensi. Instrumen penelitian ini menggunakan skala likert yang mempunyai gradasi dari sangat positif sampai sangat negatif ,yaitu sangat setuju memiliki (skor 4), setuju (skor 3), tidak setuju (skor 2) dan sangat tidak setuju (skor 1).

Uji reabilitas dan validitas kuesioner dilakukan pada 30 responden sesuai dengan kriteria inklusi dan eksklusi di luar sampel penelitian. Data yang diperoleh kemudian di uji menggunakan SPSS.

Analisis data dilakukan dengan cara mengkategorikan hasil kuesioner tingkat pengetahuan pasien tentang pengobatannya menjadi kategori kurang, cukup dan baik. Menurut Arikunto (2010), tingkat pengetahuan dikatakan baik apabila memiliki interval $75-100 \%$, cukup apabila memiliki interval $55-74 \%$, dan buruk apabila memiliki interval $\leq 55 \%$. ${ }^{1}$ Tingkat pengetahuan dihitung dengan cara sebagai berikut:

$$
\% \text { skor aktual }=\frac{\text { skor aktual }}{\text { skor } \text { ideal }} \times 100 \%
$$

Keterangan:

a. Skor aktual adalah jawaban seluruh responden atau kuesioner yang telah diajukan.

b. Skor ideal adalah skor atau bobot tertinggi atas seluruh responden diasumsikan memilih jawaban dengan skor tertinggi. Pada penelitian ini terdapat 12 pertanyaan sehingga skor idealnya adalah sebesar 48 .

Setelah perhitungan persentase skor aktual dari sampel, kemudian akan dihitung persentase untuk setiap kategori tingkat pengetahuan baik, cukup dan buruk. Penyajian data ditampilkan dalam bentuk tabel dan diagram batang.

\section{Hasil}

Penelitian ini dilakukan di tiga Puskesmas 
Kota Malang yang terpilih secara purposive sampling. Penelitian ini dilakukan selama Maret-April 2014. Besar sampel yang digunakan sebanyak 95 responden. Informasi mengenai karakteristik responden seperti usia, jenis kelamin, pendidikan terakhir, pekerjaan dan lama menderita penyakit hipertensi dapat dilihat pada Tabel 1

Sebagian besar responden berjenis kelamin perempuan sebanyak 75 responden $(38,95 \%)$. Prevalensi usia tertinggi pada kelompok usia 50-59 tahun yaitu 40 responden $(42,11 \%)$. Pendidikan terakhir terbanyak adalah sekolah dasar yaitu 45 responden $(47,37 \%)$. Pekerjaan terbanyak ibu rumah tangga, yaitu 58 responden $(61,05 \%)$. Lama menderita hipertensi terbanyak adalah 1-5 tahun yaitu 38 responden (40\%). Pengukuran tingkat pengetahuan pada penelitian ini menggunakan kuesioner tingkat pengetahuan pasien tentang penggunaan obat. Kuesioner telah di uji validitas dan reabilitasnya serta telah dinyatakan laik etik. Kuesoner yang digunakan pada penelitian ini terdiri dari pengetahuan pasien dalam meminum obat yaitu tingkat pengetahuan pasien dalam hal fungsi obat, nama obat yang diminum setiap harinya, dosis obat, waktu yang tepat untuk minum obat, cara penggunaan obat, cara kerja obat di dalam tubuh, jumlah obat yang diminum, penggunaan obat setiap hari, akibat apabila obat tidak diminum setiap hari,

Tabel 1 Distribusi Frekuensi Data Demografi Responden di Puskesmas Kota Malang

\begin{tabular}{|c|c|c|}
\hline Karakteristik & Frekuensi (n) & Persentase $(\%)$ \\
\hline \multicolumn{3}{|l|}{ Jenis kelamin } \\
\hline Laki-laki & 20 & 21,05 \\
\hline Perempuan & 75 & 38,95 \\
\hline \multicolumn{3}{|l|}{ Usia } \\
\hline $30-39$ & 2 & 2,11 \\
\hline $40-49$ & 11 & 11,58 \\
\hline $50-59$ & 40 & 42,11 \\
\hline $60-69$ & 25 & 26,32 \\
\hline $70-79$ & 14 & 14,74 \\
\hline $80-89$ & 3 & 3,16 \\
\hline \multicolumn{3}{|l|}{ Pendidikan terakhir } \\
\hline Tidak Sekolah & 13 & 13,68 \\
\hline Tidak Tamat SD & 2 & 2,11 \\
\hline SD & 45 & 47,37 \\
\hline SLTP & 15 & 15,79 \\
\hline SLTA & 15 & 15,79 \\
\hline Akademi & 5 & 5,26 \\
\hline \multicolumn{3}{|l|}{ Pekerjaan } \\
\hline PNS & 2 & 2,11 \\
\hline Swasta & 11 & 11,58 \\
\hline Wiraswasta & 14 & 14,74 \\
\hline Ibu Rumah Tangga & 58 & 61,05 \\
\hline Pensiunan & 3 & 2,16 \\
\hline Tidak Bekerja & 7 & 7,37 \\
\hline \multicolumn{3}{|l|}{ Lama Menderita } \\
\hline $2-6$ bulan & 16 & 16,84 \\
\hline 7-11 bulan & 7 & 7,37 \\
\hline $1-5$ tahun & 38 & 40 \\
\hline 6-10 tahun & 19 & 20 \\
\hline$>10$ tahun & 15 & 15,79 \\
\hline
\end{tabular}




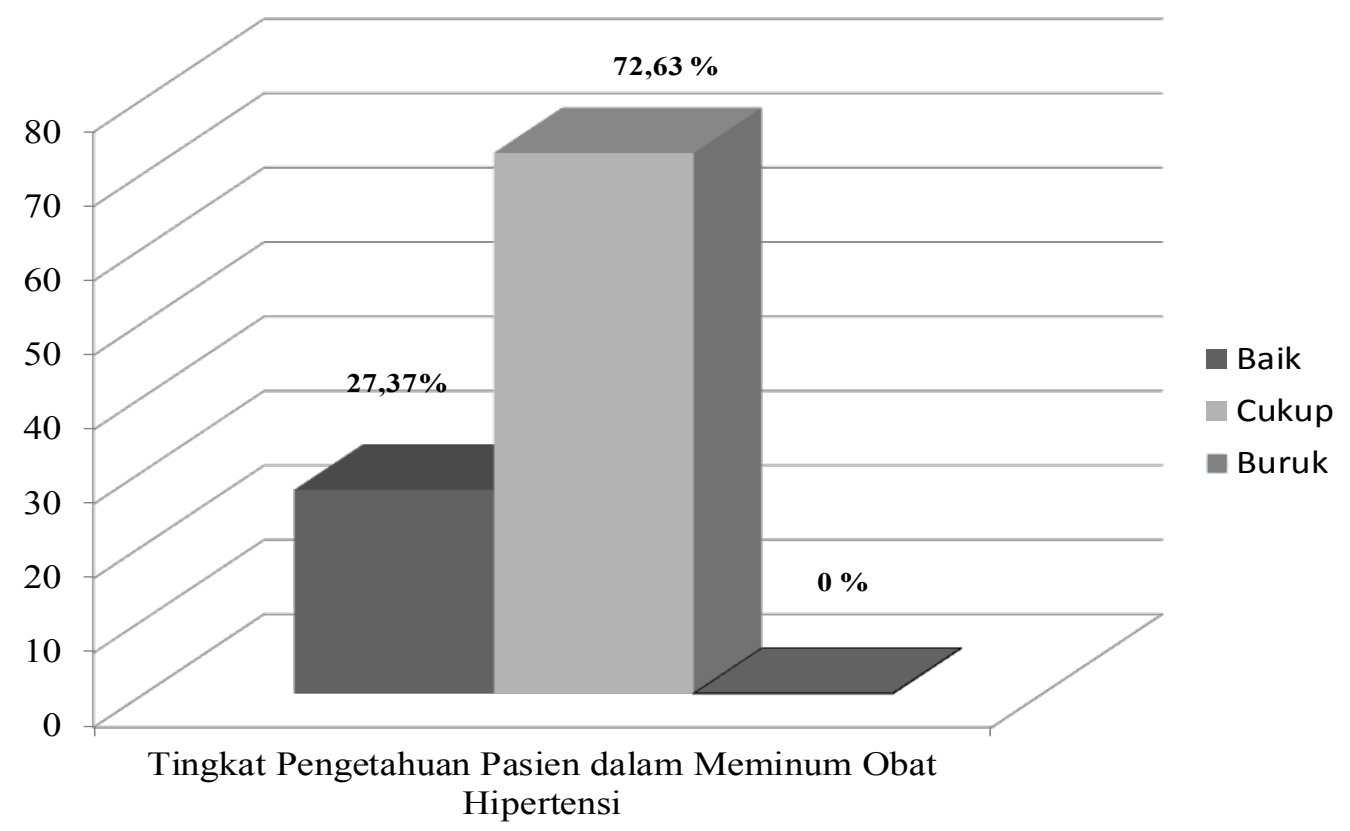

Gambar 1 Tingkat Pengetahuan Pasien dalam Meminum Obat

interaksi obat, tindakan yang dilakukan bila lupa minum obat dan cara penyimpanan obat. Kuesioner tingkat pengetahuan pasien hipertensi tentang penggunaan obat dapat dilihat di Tabel 2. Tingkat pengetahuan pasien hipertensi tentang penggunaan obat di Puskesmas Kota Malang dapat dilihat pada Gambar 1. Sebagian besar responden memiliki tingkat pengetahuan cukup tentang pengobatannya yaitu sebanyak 69 responden $(72,69 \%)$.

\section{Pembahasan}

Studi observasional secara prospektif dengan analisis deskriptif telah dilakukan untuk mengetahui tingkat pengetahuan pada pasien hipertensi mengenai pengobatannya di Puskesmas Kota Malang. Besar sampel adalah sebesar 78 responden, namun dalam penelitian diperoleh data sebanyak 95 responden dengan rincian Puskesmas Dinoyo (27 pasien), Puskesmas Kendal Sari (29 pasien) dan Puskesmas Kedung Kandang (39 pasien). Tingkat pengetahuan pasien tentang pengobatannya dapat diketahui dengan cara memberikan kuisioner kepada responden. Penelitian ini telah melalui proses review dari Komite Etik Penelitian Kesehatan Fakultas Kedokteran Universitas Brawijaya Malang dan dinyatakan laik etik.

Perempuan dan laki-laki mempunyai peluang sama terkena hipertensi. Perempuan yang berusia $>50$ lebih berisiko mengidap hipertensi karena pada wanita 50 tahun ke atas kadar estrogen menurun sehingga terapi estrogen, yaitu diduga menjaga kesimbangan kalsium. Wanita yang belum mengalami menopause dilindungi oleh hormon estrogen yang berperan dalam meningkatkan kadar High Density Lipoprotein (HDL). Kadar kolesterol HDL yang tinggi merupakan faktor pelindung dalam mencegah terjadinya proses aterosklerosis. ${ }^{2,4}$ Proporsi jenis kelamin yang paling banyak adalah perempuan sebanyak 75 responden $(38,95 \%)$.

Karakteristik individu yang paling mudah dibedakan antara satu dengan yang lainnya adalah jenis kelamin. Jenis kelamin laki-laki dan perempuan jelas sangat berbeda, tidak 
hanya dari segi fisik namun dari cara berpikir dan bertindak serta bagaimana menyikapi suatu masalah. Perempuan cenderung lebih mampu menjadi pendengar yang baik, langsung menangkap fokus diskusi dan tidak selalu berfokus terhadap diri sendiri. Sementara laki-laki dianggap tidak demikian, namun biasanya dianggap lebih mampu untuk memimpin suatu diskusi. ${ }^{8,9}$ Hipertensi bisa terjadi pada semua usia. Semakin bertambah usia seseorang, maka risiko untuk terserang hipertensi akan semakin meningkat. Pada pasien berusia $>55$ tahun tekanan darah akan otomatis meningkat dan dinding arteri mengalami penebalan karena adanya kolagen pada lapisan otot sehingga pembuluh darah akan semakin menyempit. ${ }^{2,3}$ Persentase yang tertinggi di prevalensi usia pada penelitian ini pada kelompok usia 50-59 tahun sebanyak 40 responden $(42,11 \%)$. Tingkat pengetahuan pasien hipertensi tentang pengobatannya tinggi pada usia 50-59 tahun. Pada masa ini individu mencapai puncak dari perkembangan segala kemampuan. Pengetahuannya cukup

Tabel 2 Kuesioner Tingkat Pengetahuan Pasien Hipertensi tentang Penggunaan Obat

\begin{tabular}{|c|c|c|c|c|c|}
\hline No & Keterangan & $\begin{array}{l}\text { Sangat } \\
\text { Setuju }\end{array}$ & Setuju & $\begin{array}{l}\text { Tidak } \\
\text { setuju }\end{array}$ & $\begin{array}{l}\text { Sangat tidak } \\
\text { setuju }\end{array}$ \\
\hline 1 & $\begin{array}{l}\text { Saya mengetahui penggunaan obat darah tinggi untuk } \\
\text { menurunkan tekanan darah }\end{array}$ & & & & \\
\hline 2 & $\begin{array}{l}\text { Saya mengetahui nama obat darah tinggi yang saya } \\
\text { minum sehari-hari }\end{array}$ & & & & \\
\hline 3 & $\begin{array}{l}\text { Saya mengetahui dosis obat darah tinggi yang saya } \\
\text { minum bahwa obat darah tinggi diminum tidak boleh } \\
\text { melebihi dosis yang diberikan }\end{array}$ & & & & \\
\hline 4 & $\begin{array}{l}\text { Saya mengetahui waktu yang tepat untuk meminum } \\
\text { obat darah tinggi dan saya tidak boleh melewatkan } \\
\text { waktu minum obat }\end{array}$ & & & & \\
\hline 5 & $\begin{array}{l}\text { Saya mengetahui cara penggunaan obat darah tinggi } \\
\text { yang saya minum bahwa obat darah tinggi diminum } \\
\text { per-oral (ditelan) }\end{array}$ & & & & \\
\hline 6 & $\begin{array}{l}\text { Saya mengetahui cara kerja obat darah tinggi di dalam } \\
\text { tubuh }\end{array}$ & & & & \\
\hline 7 & $\begin{array}{l}\text { Saya mengetahui jumlah obat darah tinggi yang saya } \\
\text { minum bahwa obat darah tinggi diminum sesuai dengan } \\
\text { petunjuk dokter atau apoteker }\end{array}$ & & & & \\
\hline 8 & $\begin{array}{l}\text { Saya mengetahui bahwa obat darah tinggi harus dimi- } \\
\text { num setiap hari dan saya tidak boleh lupa meminum } \\
\text { obat }\end{array}$ & & & & \\
\hline 9 & $\begin{array}{l}\text { Saya mengetahui apabila tidak meminum obat darah } \\
\text { tinggi secara rutin saya merasa pusing akibat tidak } \\
\text { mengkonsumsi obat secara rutin }\end{array}$ & & & & \\
\hline 10 & $\begin{array}{l}\text { Saya mengetahui adanya obat darah tinggi yang tidak } \\
\text { boleh diminum bersama dengan makanan atau minu- } \\
\text { man misalnya diminum bersama dengan kopi, susu, dan } \\
\text { pisang }\end{array}$ & & & & \\
\hline 11 & $\begin{array}{l}\text { Saya mengetahui apa yang harus saya lakukan apabila } \\
\text { lupa meminum obat darah tinggi bahwa tidak boleh } \\
\text { meminum obat dengan dosis dua kali lipat }\end{array}$ & & & & \\
\hline 12 & $\begin{array}{l}\text { Saya mengetahui cara penyimpanan obat darah tinggi } \\
\text { bahwa obat darah tinggi disimpan di suhu ruangan }\end{array}$ & & & & \\
\hline
\end{tabular}


luas, kecakapannya cukup banyak sehingga perkembangan individu sangat pesat. . $^{8,10}$

Pendidikan terakhir yang paling banyak adalah tamat SD sebanyak 45 responden (47,37\%). Tingkat pendidikan yang semakin tinggi akan meningkatkan tingkat intelektual seseorang sehingga akan semakin baik atau cepat menerima dan mudah menyerap informasi yang diberikan konselor, serta mempunyaipola pikiryanglebih baikterhadap penyakit dan terapi yang dijalaninya. ${ }^{8,10}$

Jenis pekerjaan sangat memiliki kaitan dengan aktivitas fisik yang dilakukan oleh seseorang. Aktivitas fisik yang dilakukan seseorang sehari-hari dapat mencegah hipertensi. Aktivitas sangat memengaruhi terjadinya hipertensi, yaitu pada orang yang kuat dalam beraktivitas akan cenderung mempunyai frekuensi denyut jantung yang lebih tinggi sehingga otot jantung akan harus bekerja lebih keras pada tiap kontraksi. Semakin keras dan sering otot jantung memompa maka makin besar tekanan yang dibebankan pada arteri. Pekerjaan yang paling banyak adalah ibu rumah tangga sebanyak 58 responden $(61,05 \%)$. Pekerjaan ibu rumah tangga mempunyai aktivitas fisik yang lebih ringan sehingga memiliki faktor risiko terkena hipertensi lebih tingggi dan dimungkinkan ada faktor resiko lain seperti stress yang dapat memicu terjadinya peningkatan aktivitas saraf simpatis sehingga tekanan darah menjadi persisten lebih tinggi dari biasanya. ${ }^{2,3}$

Lama menderita pasien hipertensi sangat mendukung terhadap pengetahuan dalam penggunaan obat. Dalam penelitian ini didapatkan data mengenai lama menderita pasien hipertensi terbanyak yaitu 1-5 tahun sebanyak 38 responden (40\%). Faktor yang memengaruhi pengetahuan seseorang adalah pengalaman dan tingkat pendidikan. Semakin lama seseorang menderita hipertensi maka pengalamannya terhadap penyakit tersebut akan bertambah pula. Pengalaman akan turut memperluas pengetahuan seseorang.
Semakin banyak pengalaman seseorang, maka semakin tinggi juga pengetahuannya. ${ }^{8,10}$

Pengetahuan pasien yang baik mengenai hipertensi akan memengaruhi kepatuhan pasien dalam meminum obat. Hal ini akan memengaruhi tekanan darah pasien sehingga komplikasi seperti jantung koroner dan kelainan ginjal tidak terjadi pada pasien. ${ }^{11,12}$ Pengetahuan responden yang baik dapat dipengaruhi oleh banyak faktor seperti pengalaman serta sarana informasi. Pengetahuan tidak hanya di dapat secara formal melainkan juga melalui pengalaman. Pengetahuan juga di dapat melalui sarana informasi yang tersedia di rumah seperti radio dan televisi. Sebagaian besar pengetahuan manusia diperoleh melalui mata dan telinga sehingga penggunaan panca indera terhadap suatu informasi sangat penting. ${ }^{8,13}$

Tingkat pengetahuan pasien hipertensi tentang pengobatannya di Puskesmas Kota Malang dibagi menjadi 3 kategori yaitu baik baik, cukup dan buruk. Kategori dari tingkat pengetahuan pasien hipertensi tentang pengobatannya dihitung dari kuesioner yang telah terisi kemudian dibandingkan dengan skor ideal dan diubah menjadi persentase. Dari hasil skor tersebut kemudian dikategorikan menjadi baik, cukup dan buruk. Berdasarkan hasil penelitian diperoleh hasil sebagian besar responden memiliki tingkat pengetahuan cukup yaitu sebanyak 69 responden $(72,63 \%)$. Responden dengan tingkat pengetahuan baik, yaitu 26 responden $(27,37 \%)$. Tidak ada responden dengan tingkat pengetahuan buruk mengenai pengobatan hipertensi.Apoteker berperan dalam meningkatkan pengetahuan pasien hipertensi tentang pengobatan karena apoteker merupakan tenaga kesehatan terakhir yang bertemu langsung dengan pasien. Apoteker dapat meningkatkan pengetahuan pasien hipertensi tentang pengobatan dengan memberikan informasi terkait obat dan non obat (life style). ${ }^{2,14}$ Kontribusi apoteker dalam meningkatkan pengetahuan pasien tidak 
hanya memberi pengetahuan terkait obat dan non obat tetapi juga memberi informasi mengenai penyakit dan komplikasi yang bisa dialami pasien jika tidak mengkonsumsi obat secara teratur. ${ }^{15}$ Diharapkan setelah apoteker memberikan informasi terkait obat dan non obat (life style), tingkat pengetahuan pasien hipertensi tentang pengobatan semakin meningkat dan kepatuhan pasien hipertensi dalam meminum obat juga dapat meningkat. Pengetahuan pasien hipertensi yang cukup mengenai pengobatan dan penyakit akan dapat mengontrol tekanan darah pasien. ${ }^{12,16}$

Meskipun pada penelitian ini diperoleh tingkat pengetahuan yang baik dan cukup, namun upaya untuk terus memberikan himbauan pentingnya menjalani pengobatan teratur bagi pasien hipertensi, mengadakan penyuluhan kesehatan mengenai penyakit hipertensi, menjamin ketersediaan Posyandu Lansia, dan memberkian brosur tentang penyakit hipertensi harus tetap dilakukan oleh Puskesmas Kota Malang. Diharapkan upaya tersebut dapat memotivasi pasien hipertensi untuk menjalani pengobatannya secara teratur. Selain itu, pasien menjadi tahu tentang penyakit hipertensi, penyebab, dan gejala yang dirasakan serta komplikasi. ${ }^{12,14}$

\section{Simpulan}

Tingkat pengetahuan pasien hipertensi tentang pengobatan di Puskesmas Kota Malang berada pada kategori cukup dan baik dengan 69 responden $(72,63 \%)$ memiliki tingkat pengetahuan yang cukup dan 26 responden memiliki tingkat pengetahuan yang baik $(27,37 \%)$.

\section{Ucapan Terima Kasih}

Penulis mengucapkan terima kasih kepada Program Studi Farmasi Fakultas Kedokteran Universitas Brawijaya yang telah menaungi penelitian ini.

\section{Pendanaan}

Pada penelitian ini sumber pendanaan berasal dari dana pribadi peneliti.

\section{Konflik Kepentingan}

Seluruh penulis menyatakan tidak terdapat potensi konflik kepentingan dengan penelitian, kepenulisan (authorship), dan atau publikasi artikel ini.

\section{Daftar Pustaka}

1. Hajjar I, Kotchen TA. Trends in prevalence, awareness, treatment, and control of hypertension in the United States. JAMA. 2005;290(2):199-206. doi:10.1001/jama.290.2.199.

2. Saseen JJ, Maclaughlin JM. In : Dipiro JT, Talbert RL, Yee GC, Matzke GR, Wells BG, Posey LM (ed). Pharmacotherapy: a pathophysiology approach, 7th Edition. New York: McGraw Hill Company; 2008.

3. Chobanian AV, Bakris GL, Black HR, Cushman WC, Green LA, Izzo JL $\mathrm{Jr}$, et al. Seventh report of the Joint National Committee on Prevention, Detection, Evaluation, and Treatment of High Blood Pressure. Hypertension. 2003;42(6):1206-52

4. HajjarI,Kotchen TA. Trends in prevalence, awareness, treatment, and control of hypertension in the United States, 19882000. JAMA. 2005;290(2):199-206. doi:10.1001/jama.290.2.199.

5. Tsuyuki RT, Semchuk W, Poirier L, Killeen RM, McAlister FA, Campbell N, et al. Canadian hypertension education program guidelines for the management of hypertension by pharmacists. Canadian Pharmacists J. 2006;139(3 suppl.1):S11S13.

6. Shahina PT, Revikumar KG, Krishnan $\mathrm{R}$, Jaleel VA, Shini VK. The impact of 
harmacist interventions on quality of life in ppatients with hypertension. Int J Pharm Sci Rev Res. 2010;5(3):31.

7. Arikunto A. Prosedur penelitian: suatu pendekatan praktek (ed revisi). Jakarta: Rineka Cipta; 2010.

8. Notoatmojo S. Promosi kesehatan dan ilmu perilaku. Jakarta: Rineka Cipta; 2007.

9. Carter BL, Barnette DJ, Chrischilles E, Mazzotti GJ, Asali ZJ. Evaluation of hypertensive patients after care provided by community pharmacists in a rural setting. Pharmacotherapy. 2005;17(6): 1274-85. doi: 10.1002/j.1875-9114.1997. tb03092.x

10. Sabouhi F, Babaee S, Naji H, Zade AH. Knowledge, awareness, attitudes and practice about hypertension in hypertensive patients referring to public health care centers in Khoor \& Biabanak 2009. Iran J Nurs Midwifery Res. 2011;16(1):35-41.

11. Ike S. Prevalence of hypertension and its complications among medical admissions at the University of Nigeria Teaching Hospital Enugu (Study 2). Niger J Med. 2009;18(1):68-72.

12. Sharma S, Bhuvan KC, Alrasheedy AA, Kaundinnyayana A, Khanals A. Impact of community pharmacy-based educational intervention on patients with hypertension in Western Nepal. Australasian Medical J. 2014;7(7):304-13. doi: 10.4066/ AMJ.2014.2133

13. Lam JY, Guirguis LM. Patient's blood pressure knowledge, perceptions and monitoring practices in community pharmacies. Pharmacy Practice. 2010;8(3):187-92.

14. Lee JK, Grace KA, Taylor AJ. Effect of a pharmacy care program on medication adherence and persistence, blood pressure, and low-density lipoprotein cholesterol: a randomized controlled trial. JAMA. 2006;296(21):2563-71. doi:10.1001/jama.296.21.joc60162.

15. Zillich AJ, Sutherland JM, Kumbera PA, Carter BL. Hypertension outcomes through blood pressure monitoring and evaluation by pharmacists (HOME study). J Gen Intern Med. 2005;20(12):1091-6. doi: 10.1111/j.1525-1497.2005.0226.x

16. Roughead EE, Semple SJ, Vitry AI. Pharmaceutical care services: a systematic review of published studies, 1990 to 2003, examining effectiveness in improving patient outcomes. Int J Pharm Pract. 2005;13:53-70. doi: $10.1211 / 0022357055551$ 